Society for the Anthropology of Work • Essential Labor

\title{
While Others Sleep: The Essential Labor of Migrant Nightshift Workers
}

\section{Julius-Cezar MacQuarie}

Published on: Sep 16, 2020

DOI: 10.21428/1d6be30e.fb029d9b

License: Creative Commons Attribution 4.0 International License (CC-BY 4.0). 
When society sleeps, who must remain awake? Nightworkers are by definition essential workers, whose hidden labor makes other sectors of the economy possible. And, in postindustrial societies, it is mostly migrants who work the night shift. The COVID-19 pandemic has disrupted the organization of work for many laborers. But, for nightworkers, the designation of frontline daytime laborers as essential has implicitly cast those who work backstage and through the night as expendable. This temporal politics demonstrates the existence of different layers of precarity within our labor system.

All nightworkers are subject to precarity, insofar as they need to stay alert during the hours when human bodies are supposed to rest. This precarity is further aggravated in the case of migrants, who are more likely than locals to accept deskilled jobs on precarious working terms (that is, without a work contract and at unsociable hours). My ethnographic research with migrant workers at London's New Spitalfields night market, Britain's largest wholesale fruit, vegetable, and flower market, revealed how the categories of migrant/nonmigrant and day shift/night shift articulated with one another. By laboring next to these workers six nights per week and by gathering thick data with a range of methods, I was able to document the precarity of their living and working conditions. In this piece, I extend that research into the present moment and show how the overall effect of the COVID-19 pandemic has been to further amplify the precarity of migrant nightwork.

\section{Burdened Bodies, Precarious Lives}

In the United Kingdom, more than one worker in nine works in the night-time economy, amounting to some 3.25 million people. London has the country's secondlargest contingent of nightworkers after southeast England, where care workers, nurses, and midwives account for the majority of nightworkers. In global cities such as London the polarization of the labor market is especially visible, with high-flying executives at one end and manual workers, mostly migrants, in low-wage occupations at the other.

Murad is a nightworker who falls into the latter category. He came to London from an EU country in search of work and, for nine years, spent his nights working as a loader and porter at the New Spitalfields night market. In our conversations, Murad often mentioned a feeling of being trapped by his lack of job prospects outside of the market. "If I wanted to work in day jobs, I would need to speak English better," he explained. "But because I have not improved my language skills, I will continue doing the night 
shifts. We'll see for how long." Earlier this year, he reflected: "I've been saying the same thing all these years. And I am still working at the market, no matter how many times I tried to find work elsewhere. But this is the last year I am working nights."

There was a sense of exasperation in Murad's eyes as he admitted this. Exhaustion had been mounting for nearly a decade. Migrants like Murad may initially perceive nightwork, which is better paid than the kinds of daytime work for which they have the necessary skills, as a lucrative way to make money fast and return to their home countries. In reality, though, many never return home and have to deal with the negative impact that manual overnight work has on their health and their social lives. Under late capitalism, the expansion of nightwork can be seen as a temporal fix, that is, a response to the need to make production and consumption happen around the clock (Harvey 2001; Crary 2013). Yet this version of 24/7 capitalism refuses to recognize or find solutions for the problems that nightwork poses, from lack of decent working conditions to the seizure of private time for self-development and sociality.

Just before the lockdown came into force this spring, Murad lost his forklift driver's license when he was caught exceeding the speed limit enforced on the market's premises. Thus, he became unemployed at the very moment when the night market was reducing its activity, catering as it does to many sectors that are now considered nonessential. Under these conditions, Murad could not find another job at the market even as his chances of finding something elsewhere were limited. With less daywork in the overall economy to be reproduced, Murad's nightwork was rendered extraneous.

Among the work sectors hit most heavily by layoffs during the pandemic were hospitality and accommodation, which rely heavily on foreign-born workers. As many as 25 percent of foreign-born workers in the United Kingdom have been affected by the disruptions (Fernández-Reino, Sumption, and Vargas-Silva 2020). These workers have been deemed nonessential and furloughed; some risk losing their jobs altogether without urgent government support. This nonessential workforce has been left to its own devices without family support or savings, away from public attention. In a sense, migrant nightworkers are three times as invisible as locals in daytime frontline work, leaving them politically vulnerable.

In postindustrial countries precarious, low-paid, back-breaking work is typically reserved for migrant workers (Ruhs and Anderson 2010). In low-waged occupations, on both the day and night shifts, delivery drivers, hospital cleaners, and workers in food manufacturing and supply chains tend to be migrants. As these workers have been thrust into the spotlight and classified as essential during the pandemic, changes 
in public perception of migrant workers have ensued. Media accounts have cast migrants doing essential work in a positive light. Thus, as reductive as the category of "essential" may be, the COVID-19 crisis has served to draw two previously distant conceptual categories close: that of the migrant and that of the valued worker.

Yet Lexa's attempts to balance a life spent between day sleep and nightwork shows the limits of this discursive turn. Like Murad, Lexa migrated from the European continent to work in the United Kingdom. On her first day in the country, she began working in the New Spitalfields night market as a café server. As she summed up this period: "In the morning, you get home tired, you sleep, you have no time for the children. You wake up two hours before the night shift . . . my life was spent on work, sleep, work." Although Lexa worked six nights per week, like many other nightworkers at the market she had also taken day jobs to make ends meet. "My body was exhausted," she recalled. "I became dependent on energy drinks because I couldn't keep going anymore."

Migrant nightshift workers' bodies become spent through precarity, in the forms of working poverty, job instability, and unsteady income. They labor in a capitalist regime of discipline that attempts to extract as much as possible from their disposable bodies. Any possibilities of organizing dissolve in the consuming experience of physical labor (MacQuarie 2018). As Lexa recounted: "I asked [my manager] to give me one night off, but he wouldn't have it. So I didn't turn up for the next shift. He cut two nights' worth of wages even though I only missed one shift." The production of worker solidarities is further undermined by a schedule opposite to the one kept by traditional labor organizations.

After four years, Lexa stopped working full-time at the night market. As of 2019, she was self-employed as a taxi driver, mostly working nights. Earlier this year, before the lockdown, we met and she told me she was happy with how things were turning out for her and her daughter. But once the lockdown started, taxi driver jobs were also deemed nonessential. By April, Lexa's situation had changed drastically. She explained: "I stopped working since the COVID-19 situation and I have lots of bills to pay. I took a three-month reprieve on my car loan, but the rent still needs paying. It's been really tough!" The last time we spoke, she told me that "it will work out somehow." She is again driving her taxi at night from time to time. 


\section{Invisible Yet Essential, Pandemic or Not}

Postindustrial societies rely 24/7 on invisibilized migrant labor in low-wage occupations, which is carried out by workers like Murad and Lexa. Even as the pandemic has resulted in some public acknowledgement of their contributions, the darkness of night leaves them underserved and out of view. While precarity is not restricted to nightwork alone, being a migrant and working at night magnifies precarity by several degrees. Even though Murad and Lexa's work is no less indispensable during these exceptional times, the triple bind of migrant nightwork has resulted in their classification as expendable.

When dayworkers go to sleep, migrant nightworkers carry the burdened night on their bodies. They have done so before the pandemic and will continue doing so long after it, somehow managing to balance income, expenses, and social life in spite of the categories imposed on them. However, the COVID-19 crisis presents an opportunity to recognize the essential nature of migrant nightwork and to reflect on its current placement at the lowest level of our labor system. Not unlike the spatial axis of exclusion that has rendered domestic labor invisible under capitalism (Weeks 2011), nightwork foregrounds a temporal axis that results in a parallel process of invisibilization. The failure to recognize the essential nature of nightwork must be understood as one reason for its continued, troubling precarity.

\section{Acknowledgments}

Thanks to Violetta Zentai for her continuous support, to Ger Duijzings for the inspiring night walks in London, and to Magdalena Craciun for her critical input. Special thanks to Josh Fisher and Marcel LaFlamme for their insightful comments on previous versions of this piece.

\section{Author Bio}

Julius-Cezar MacQuarie is an anthropologist trained at Central European University who is concerned with the invisibility of migrant nightshift workers in public debates. MacQuarie writes on nightwork, precariousness, and decent work, and is also a Migrant Voice Ambassador.

\section{Preview Image}

Courtesy of Gilbert Mercier. 


\section{References}

Crary, Jonathan. 2013. 24/7: Late Capitalism and the Ends of Sleep. New York: Verso.

Fernández-Reino, Mariña, Madeleine Sumption, and Vargas-Silva, Carlos. 2020. "From Low-Skilled to Key Workers: The Implications of Emergencies for Immigration Policy." Oxford Review of Economic Policy, May 19.

Harvey, David. 2001. Spaces of Capital: Towards a Critical Geography. New York: Routledge.

MacQuarie, Julius-Cezar. 2018. “Invisible Migrants: Glocturnal Cities' 'Other Workers' in the Post-Circadian Capitalist Era." PhD dissertation, Central European University.

Ruhs, Martin, and Bridget Anderson. 2010. "Migrant Workers: Who Needs Them? A Framework for the Analysis of Staff Shortages, Immigration, and Public Policy." In Who Needs Migrant Workers? Labor Shortages, Immigration, and Public Policy, edited by Martin Ruhs and Bridget Anderson, 15-52. New York: Oxford University Press.

Weeks, Kathi. 2011. The Problem with Work: Feminism, Marxism, Antiwork Politics, and Postwork Imaginaries. Durham, NC: Duke University Press. 